Іманов Е. ${ }^{1}$, канд. мед. наук

Труба Я. П. ${ }^{1}$, канд. мед. наук, завідувач відділу хірургічного лікування вроджених вад серця у новонароджених та дітей молодшого віку

Дзюрий І. В. ${ }^{1}$, лікар-кардіохірург відділення хірургічного лікування вроджених вад серця у новонароджених та дітей молодшого віку

Плиска 0. І. ${ }^{3}$, д-р мед. наук, професор, завідувач кафедри біології

Лазоришинець В. В., ${ }^{1,2}$ д-р мед. наук, академік НАМН України, професор, директор інституту, завідувач кафедри

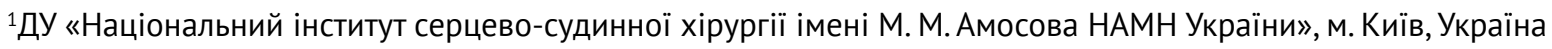

${ }^{2}$ Кафедра хірургії серця та магістральних судин, Національна медична академія післядипломної освіти

імені П. Л. Шупика, м. Київ, Україна

${ }^{3}$ Національний педагогічний університет імені М. П. Драгоманова, м. Київ, Україна

\title{
Порівняльна характеристика хірургічного лікування та балонної вальвулопластики в немовлят з критичним аортальним стенозом
}

\begin{abstract}
Резюме. Критичний аортальний стеноз (АС) у немовлят є складною патологією, що потребує надання невідкладної допомоги. Лікування таких пацієнтів - комплексна та складна проблема. Методи лікування включають балонну вальвулопластику та відкриту хірургічну вальвулопластику.

Мета роботи - проаналізувати власний досвід хірургічного лікування та балонної вальвулопластики критичного аортального стенозу в немовлят.

Матеріали та методи. За період з 2006 по 2018 рік в ДУ «Національний інститут серцево-судинної хірургії імені М. М. Амосова НАМН України» було проліковано 58 немовлят з АС. При цьому 47 (81 \%) пацієнтам (І група) було виконано рентгенендоваскулярну балонну вальвулопластику аортального стенозу, а 11 (19 \%) пацієнтам (II група) проведене хірургічне лікування.

Результати та обговорення. Після балонної вальвулопластики відзначалося значне зниження градієнта тиску на аортальному клапані (АК) у пацієнтів I групи та підвищення фракції викиду лівого шлуночка (ФВ ЛШ), проте у середньовіддаленому терміні спостереження градієнт тиску на АК в більшості пацієнтів підвищився та почала наростати аортальна недостатність. Після хірургічної корекції відзначалися добрі безпосередні та середньовіддалені результати відносно градієнта тиску на АК та ступеня недостатності.

Заключення. Як хірургічна, так і балонна вальвулопластика є ефективними методами лікування АС у немовлят з добрими безпосередніми результатами. Проведене дослідження вказує на те, що балонна вальвулопластика може бути прийнятною альтернативою хірургічному лікуванню в пацієнтів у критичному стані з ознаками вираженої серцевої недостатності, але має тенденцію до наростання аортальної недостатності у віддаленому періоді.
\end{abstract}

Ключові слова: аортальний стеноз, хірургічна аортальна вальвулопластика, балонна вальвулопластика, немовлята.

Вступ. Аортальний стеноз (АС) - це група врождених вад сердця, обумовлена порушенням відтоку крові з лівого шлуночка (ЛШ). Критичний АС у немовлят становить складну патологію, що потребує надання невідкладної допомоги. Серед усіх вроджених вад серця (ВBC) ця вада становить від 2 до $11 \%$. Виділяють: клапанний аортальний стеноз, який спостерігається у 58-70\% випадків, підклапанний - 20-25\% і надклапанний - 5-10\% серед усіх аортальних стенозів. У хлопчиків ця ВВС розвивається в 4 рази частіше, ніж у дівчаток. У 1956 році Lillehei та співавтори запропонували вальвулотомію аортального клапана в умовах штучного кровообігу, яка протягом 30 років залишалась золотим стандартом лікування стенозу АК. У 1983 році Lababidi в Університеті Miсcурі описав нову методику застосування балонної вальвулопластики. Починаючи з 90-х років минулого століття у зв'язку з накопиченням віддалених результатів обох методик підхід до лікування АС став вибірковим. Навіть сьогодні, незважаючи на значний досвід різних клінік, немає чітких критеріїв для вибору того чи іншого методу [1]. Особливо це стосується новонароджених і немовлят. В ідеалі початкове втручання повинно адекватно знизити градієнт тиску на рівні AK [2], не спричинюючи значної регургітації. Балонна аортальна вальвулопластика та хірургічна аортальна вальвулотомія є конкуруючими методами, 
і вибір первинного втручання, як правило, грунтується на преференціях тієї чи іншої установи. Перевагами балонної вальвулотомії є малоінвазивність, швидкість проведення, що особливо важливо в декомпенсованих пацієнтів, а також відсутність тривалого наркозу і гемотрансфузій $[2,3]$. Під час хірургічної корекції є можливість під візуальним контролем виконати не тільки операцію щодо усунення стенозу, а й спрямувати пластичні втручання на усунення регургітації на клапані. Залежно від анатомії вади виділяють різні методи хірургічного лікування: аортальна вальвулопластика, операція Ross i Ross - Konno, Damus - Kaye - Stansel, аортальний клапан може бути замінений донорським алографтом або бути виготовленим з аутоперикарда, але основною задачею в лікуванні цієї проблеми є збереження власного АК, що дає можливість до його подальшого росту, збільшує період між реопераціями, а інколи зовсім виключає необхідність повторних втручань і не потребує антикоагулянтної терапії.

Одні клініки сьогодні обирають балонну вальвулопластику як первинний метод лікування через низьку летальність і відносно малу кількість ускладнень [4], інші - відкриту хірургічну вальвулопластику [5]. При застосуванні балонної вальвулопластики частіше виявляється недостатність і стеноз клапана в післяопераційному періоді, що часто потребує повторних операцій [6].

Мета роботи - провести порівняльний аналіз хірургічного лікування та балонної вальвулопластики критичного аортального стенозу в немовлят.

Матеріали та методи дослідження. Із січня 2006 по грудень 2018 року в ДУ «Національний інститут серцево-судинної хірургії імені М. М. Амосова НАМН України» госпіталізовано 58 пацієнтів з критичним АС. 3 них: 43 хлопчики (74\%), 15 дівчаток (26\%). При цьому 47 (81\%) пацієнтам (І група) було виконано рентгенендоваскулярну балонну вальвулопластику АС, а 11 (19 \%) пацієнтам (II група) проведене хірургічне лікування.

Середній вік пацієнтів I групи становив $20 \pm 14,3$ доби (від 2 до 60 діб), середня маса тіла $-3,4 \pm 1,5$ кг (від 2,5 до 7 кг). У II групі середній вік пацієнтів становив $125 \pm 72,4$ доби (від 28 до 320 діб), середня маса тіла $-5,8 \pm 1,4$ кг (від 3,5 до 8,7 кг). У 23 (39,5 \%) пацієнтів обох груп вада була діагностованна пренатально та підтверджена за допомогою ехокардіографії (ЕхоКГ) відразу після народження, що дозволило терміново доставити дитину в ДУ НІССХ ім. М. М. Амосова НАМН України для надання висококваліфікованої хірургічної допомоги. До операції градієнт на аортальному клапані в пацієнтів I групи за даними ЕхоКГ сягав 67,6 \pm 19 мм рт. ст. (від 30 до 114 мм рт. ст.), у ІІ групі $69 \pm$ 23 мм рт. ст. (від 29 до 120 мм рт. ст.). Критеріями вибору тактики лікування під час госпіталізації були: максимальний градієнт тиску на $\mathrm{AK} \geq 60$ мм рт. ст., при середньому значенні $\geq 40-45$ мм рт. ст., знижена фракція викиду ЛШ (ФВ ЛШ).
Як видно з описання, групи порівняння є досить різнорідними. Причиною такої різнорідності є показання до різних видів втручання. За умови стабільного стану пацієнтів та наявних гемодинамічних показань до втручання віддавали перевагу виконанню хірургічної корекції в умовах штучного кровообігу. Балонна вальвулопластика була пріоритетною для декомпенсованих пацієнтів з ФВ меншою за $45 \%$ та за наявності супутньої патології або вторинних змін з боку систем органів.

Усім пацієнтам перед операцією, а потім інтраопераційно та у післяопераційному періоді виконували загальноклінічні, біохімічні, бактеріологічні дослідження. Усім хворим записували електрокардіографію, виконували рентгенографію органів грудної клітки в прямій проекції, ЕхоКГ. 3 метою підтвердження та уточнення діагнозу й, особливо, діагностики супутніх BBC 5 (10\%) пацієнтам I групи та 2 (18\%) пацієнтам II групи виконували комп'ютерну томографію. У таблиці 1 наведені супутні ВВС.

Основним методом діагностики у визначенні вади та оцінюванні безпосередніх і віддалених результатів було ЕхоКГ дослідження, що дало змогу оцінити морфологію, кінетику структур серця, стан гемодинаміки. Пацієнтам з критичним АС після народження і до безпосереднього проведення оперативного втручання, для підтримки адекватної системної перфузії, здійснювали інфузію простагландину $\mathrm{E}_{1}$ (у розрахунковій дозі 0,05 $0,1 \mathrm{мкг/кг} \mathrm{•} \mathrm{хв)} \mathrm{для} \mathrm{запобігання} \mathrm{закриттю} \mathrm{відкритої} \mathrm{ар-}$ теріальної протоки та розвитку кардіогенного шоку. За потреби призначали інотропні препарати та проводили корекцію метаболічного ацидозу. Після стабілізації функціонального стану новонародженого виконували оперативне лікування АС чи балонну вальвулопластику.

Балонну вальвулопластику здійснювали за стандартною методикою: пункційний доступ - права або ліва феморальні артерії, використовували гідрофільний інтродюсер 4F. Після аорторграфії АK проходили гідрофільним провідником, використовуючи катетер

\section{Таблиця 1}

\section{Супутні BBC у пацієнтів з $A C$}

\begin{tabular}{lcc} 
Супутні ВВС & I група & II група \\
\hline Гіпоплазія ЛШ & $1(2 \%)$ & - \\
\hline Гіпоплазія дуги аорти & $7(14 \%)$ & $3(27 \%)$ \\
\hline ДМПП & $4(8 \%)$ & $1(9 \%)$ \\
\hline ДМШП & - & $1(9 \%)$ \\
\hline Субаортальний стеноз & $1(2 \%)$ & - \\
\hline ЧАДЛВ & $1(2 \%)$ & - \\
\hline Гіпоплазія дуги аорти & - & $1(9 \%)$
\end{tabular}

Примітка. ДМПП - дефект міжпередсердної перегородки; ДМШП - дефект міжшлуночкової перегородки; ЧАДЛВ - частковий аномальний дренаж легеневих вен. 
Jadkins Right або МРА. Для дилатації брали балон завдовжки 20-30 мм і діаметром, що становить $80 \%$ від розміру клапана аорти. За неефективності процедури діаметр балона збільшували, але так, щоб він не перевищував діаметр клапанного кільця. Після процедури транскатетерно оцінювали градієнт систолічного тиску та недостатність АК при аортографії.

Усім пацієнтам хірургічної групи операції проводили через серединну стернотомію в умовах штучного кровообігу та фармакохолодової кардіоплегії розчином Кустодіол. Залежно від анатомії вади виконували комісуротомію зрощених нативних або псевдокомісур, видалення надлишкової тканини фіброзно та міксоматозно змінених стулок клапана. Інтраопераційно, після відключення штучного кровообігу проводили трансстравохідне ЕхоКГ дослідження для оцінювання залишкового градієнта та ступеня недостатності АК.

Результати та обговорення. У I групі госпітальна летальність становила $6,8 \%(\mathrm{n}=4)$. У двох пацієнтів післяопераційний період ускладнився двобічною пневмонією, сепсисом, і пацієнти померли на 15-у і 20-у добу після процедури від наростаючої дихальної та поліорганної недостатності. В одного пацієнта причиною лівошлуночкової недостатності став виражений фіброеластоз ЛШ з переходом на АК через 5 днів після народження, і на 2-й день після процедури пацієнт помер. Причиною ще одного летального випадку була тромбоемболія черевного відділу аорти з гострим інфарктом нирок та вроджена дисплазія обох нирок, смерть настала на 30-й день після процедури. Також слід наголосити, що всі летальні випадки були обумовлені попередньо тяжким станом пацієнтів, які були госпіталізовані в клініку.

Летальних випадків у II групі не відзначалося. Серед пацієнтів II групи у 10 з них була виконана первинна відкрита аортальна вальвулотомія, в одного - через 15 діб після балонної вальвулопластики операція Ross - Konno. Тривалість штучного кровообігу в середньому становила $73 \pm 12$ хв (від 47 до 265 хв), час перетискання аорти $-47 \pm 5$ хв (від 23 до 78 хв). Інтраопераційно функціонально двостулковий АК був у 9 пацієнтів (81\%), тристулковий - у 2 пацієнтів (19\%). Причинами стенозу, які виявили під час операції, були зрощення між собою (з наявністю однієї або двох псевдокомісур) стулок клапана в усіх пацієнтів, у 7 (63\%) пацієнтів додатково діагностували фіброзно змінені і міксоматозно потовщені стулки клапана.

Ускладнення раннього післяопераційного періоду відзначались у 16 (34 \%) дітей I групи та проявлялись у вигляді дихальної та серцевої недостатності. У 6 (54 \%) дітей II групи спостерігалася систолічна та діастолічна дисфункція ЛШ, ексудативний плеврит, серцева недостатність (таблиці 2).

Як видно з таблиці, кількість ускладнень у пацієнтів I групи $\mathrm{n}=16$ (34 \%) статистично достовірно відріз-

\section{Таблиця 2}

Ускладнення госпітального етапу

\begin{tabular}{lcc} 
Ускладнення & $\begin{array}{c}\text { I група } \\
\text { Балонна вальвуло- } \\
\text { пластика } \\
\text { (n= 47) }\end{array}$ & $\begin{array}{c}\text { II група } \\
\text { Хiрургія } \\
\text { (n= 11) }\end{array}$ \\
\hline Серцева недостатність & 6 & 1 \\
\hline Дихальна недостатність & 5 & - \\
\hline Ранова інфекція & 0 & - \\
\hline $\begin{array}{l}\text { Систолічна та діастолічна } \\
\text { дисфункція ЛШ }\end{array}$ & 0 & 3 \\
\hline $\begin{array}{l}\text { Часткові ателектази } \\
\text { легень }\end{array}$ & 3 & - \\
\hline Гемотрансфузії & 2 & 1 \\
\hline Ексудативний плеврит & - & 1 \\
\hline Усього & $\mathbf{1 6}(34 \%)$ & $\mathbf{6 ( 5 4} \%)$
\end{tabular}

нялась, ніж у пацієнтів II групи $\mathrm{n}=6(54 \%)$, p Value $<0,05$.

Час штучної вентиляції легень у середньому після дилатації в I групі становив $31 \pm 12$ год (від 5 до 298 год). Час перебування в реанімації - 3 доби (від 2 до 40 діб). Час штучної вентиляції легень після операції в II групі сягав $38 \pm 16$ год (від 8 до 330 год). Час перебування в реанімації - 5 діб (від 3 до 60 діб). За даними ЕхоКГ, яку виконували планово протягом 24 год 3 моменту операції, відзначено достовірне зниження градієнта як у І групі з 65,2 $\pm 2,7$ до $30,3 \pm 3$ мм рт. ст. (р < $0,05)$, так і в II групі з 79,1 $\pm 5,5$ до $32,73 \pm 3,18$ мм рт. ст. $(\mathrm{p}<0,05)$. Суттєве підвищення ФВ ЛШ відзначали в пацієнтів I групи, в яких при поступленні ФВ ЛШ становила 48,21 $\pm 3,1 \%$ (від 18 до $75 \%$ ), а при виписуванні $-60,2 \pm 1,67 \%$ (від 55 до $75 \%$ ). У пацієнтів II групи ФВ ЛШ особливо не змінилась і становила до операції $65,82 \pm 4,33 \%$ (від 59 до $75 \%$ ), а на момент виписування $-67,82 \pm 2,9 \%$ (від 65 до $85 \%$ ).

Дані ехокардіографічного дослідження пацієнтів на різних етапах лікування наведено в таблиці 3.

Як видно з таблиці 3, ФВ ЛШ відновилася після балонної вальвулопластики в усіх пацієнтів і в подальшому зберігалася на достатньому рівні, що підтверджує ефективність цього методу в пацієнтів з ознаками вираженої серцевої недостатності. У всіх пацієнтів показники середнього градієнта на АK в групах порівняння на момент виписування майже не відрізнялись, але протягом року після балонної вальвулопластики градієнт тиску на АК виріс. Після хірургічної корекції відзначалися добрі безпосередні та середньовіддалені результати відносно градієнта тиску на АК.

Проведений аналіз середньовіддалених результатів показав, що в більшості пацієнтів I групи з часом відзначається тенденція до зростання ступеня аортальної недостатності, що може стати приводом у майбутньо- 


\section{Таблиця 3}

Показники ЕхоКГ на різних етапах лікування

\begin{tabular}{|c|c|c|c|}
\hline Показник & $\begin{array}{l}\text { I група } \\
(n=47)\end{array}$ & $\begin{array}{l}\text { II група } \\
(n=11)\end{array}$ & p-value \\
\hline $\begin{array}{l}\text { Середній градієнт до } \\
\text { операції (мм рт. ст.) }\end{array}$ & $65,2 \pm 2,7$ & $79,1 \pm 5,5$ & $<0,05$ \\
\hline $\begin{array}{l}\text { Середній градієнт після } \\
\text { операції (мм рт. ст.) }\end{array}$ & $30,3 \pm 3$ & $32,73 \pm 3,18$ & 0,16 \\
\hline $\begin{array}{l}\text { Середній градієнт тиску } \\
\text { через } 12 \text { місяців }\end{array}$ & $38,2 \pm 3,5$ & $31 \pm 2,8$ & 0,28 \\
\hline $\begin{array}{l}\text { Середній градієнт тиску } \\
\text { через } 36 \text { місяців }\end{array}$ & $45,2 \pm 1,7$ & $29,1 \pm 2,4$ & $<0,05$ \\
\hline ФВ ЛШ до операції (\%) & $48,21 \pm 3,1$ & $65,82 \pm 4,33$ & $<0,05$ \\
\hline $\begin{array}{l}\text { ФВ ЛШ після операції } \\
\text { (\%) }\end{array}$ & $60,2 \pm 1,67$ & $67,82 \pm 2,9$ & $<0,05$ \\
\hline $\begin{array}{l}\text { ФВ ЛШ через } \\
12 \text { місяців }\end{array}$ & $62,3 \pm 1,9$ & $67,2 \pm 2,1$ & 0,26 \\
\hline $\begin{array}{l}\text { ФВ ЛШ через } \\
36 \text { місяців }\end{array}$ & $65,2 \pm 2,4$ & $68 \pm 1,9$ & 0,08 \\
\hline $\begin{array}{l}\text { Час штучної вентиляції } \\
\text { легень (години) }\end{array}$ & $31 \pm 12$ & $38 \pm 16$ & $<0,05$ \\
\hline $\begin{array}{l}\text { Перебування у } \\
\text { відділенні реанімації } \\
\text { та інтенсивної терапії } \\
\text { (доби) }\end{array}$ & 3 & 5 & $<0,05$ \\
\hline Госпітальна летальність & $4(8,5 \%)$ & - & 0,41 \\
\hline
\end{tabular}

му до повторних операцій, на відміну від II групи (рисунок 1).

Середній термін спостереження становив $36 \pm 5$ місяців (від 10 до 60 місяців). У звязку із наростанням гра-

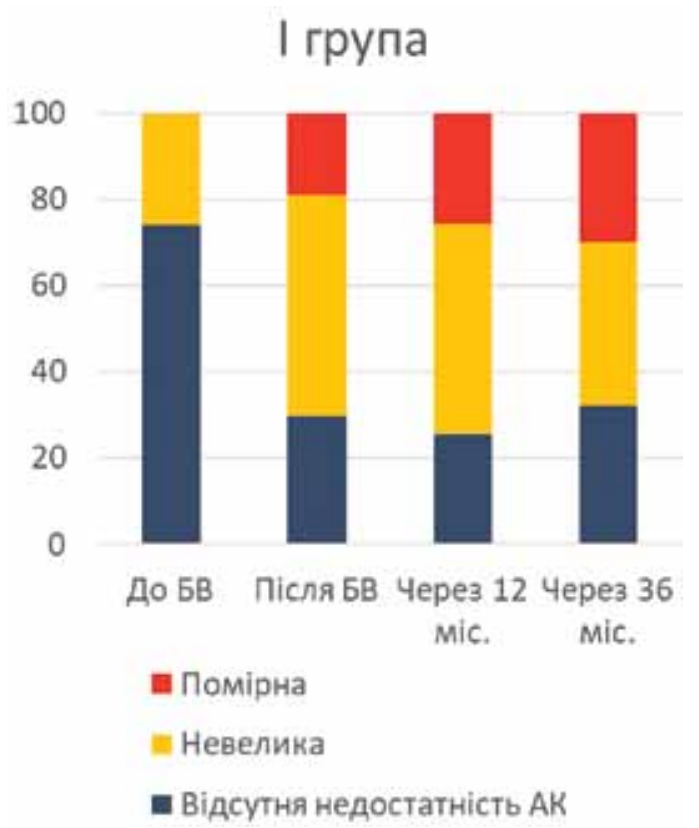

дієнта тиску на АК 2 (4 \%) пацієнтам I групи через 12 i 18 місяців виконали відкриту аортальну вальвулотомію. У II групі 1 (9\%) пацієнту, якому в період новонародженості виконали аортальну вальвулотомію і пластику дуги аорти з приводу критичного аортального стенозу й гіпоплазії дуги аорти через 36 місяців у зв'язку з аортальним рестенозом виконали операцію Ross - Konno.

Незважаючи на досягнення сучасної дитячої кардіохірургії, оптимальна тактика лікування при вродженому стенозі АK у новонароджених та немовлят залишається спірною. Це пов'язано з вихідним критичним станом пацієнтів, травматичністю і обсягом втручання, високим відсотком ускладнень і повторних операцій. Порівнюючи балонну вальвулопластику та хірургічну вальвулотомію в дітей, які мають вроджений стеноз АК, частина авторів демонструє відсутність відмінностей у довгостроковій виживаності або швидкості заміни АК, водночас вказуючи на вищі показники повторних втручань після балонної вальвулопластики, інші засвідчують переваги саме хірургічного методу лікування. Так, Siddiqui J. та співавтори показали достовірно кращий показник свободи від реінтервенцій та заміни АК після хірургічного втручання. У цьому дослідженні автори доводили це удосконаленням хірургічної техніки, у тому числі стоншенням стулок і резекцією вузлової дисплазії. Літературні дані свідчать, що методом вибору при лікуванні критичного АС, здатним вірогідно покращити прогноз і подовжити термін до реоперації, є хірургічна корекція вади. Балонна вальвулопластика характеризується низкою недоліків, зокрема високим ризиком ускладнень, значною ймовірністю рецидиву обструкції, високою інтраопераційною

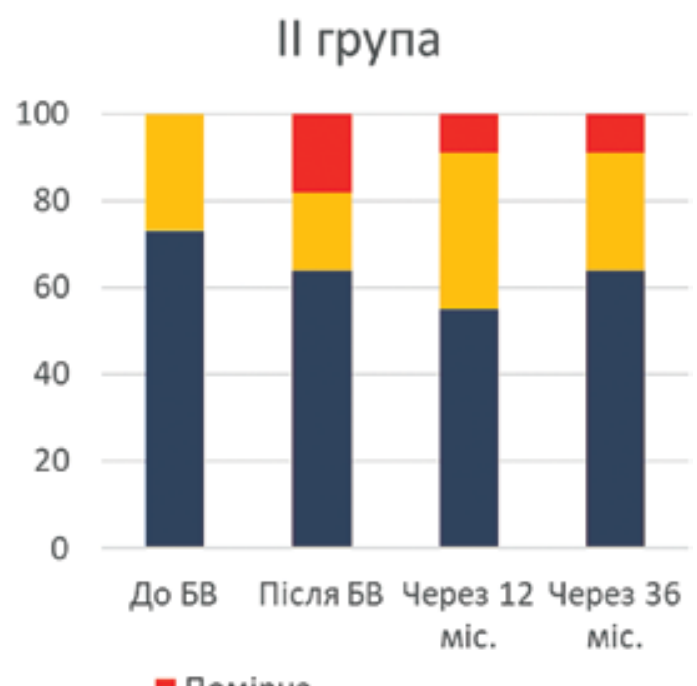

Помірна

Невелика

Відсутня недостатність АК

Рисунок 1. Динаміка показників аортальної недостатності в групах порівняння 
летальністю 4 (8,5 \%), проте має право на існування, особливо в пацієнтів у критичному стані [6].

\section{Висновки}

1. Як хірургічне лікування, так і балонна вальвулопластика $є$ ефективними методами лікування АС у немовлят з добрими безпосередніми результатами, що потребує подальших досліджень у віддаленому післяопераційному періоді для обгрунтованого вибору хірургічного методу втручання та прогнозування результатів лікування.

2. Проведене дослідження вказує на те, що балонна вальвулопластика може бути прийнятною альтернативою хірургічному лікуванню в пацієнтів з ознаками вираженої серцевої недостатності, яка є безпечним, малотравматичним і ефективним методом усунення AC і може бути методом вибору в таких пацієнтів як перший етап лікування.

3. Аналіз безпосередніх і середньовіддалених результатів балонної вальвулопластики в немовлят показав тенденцію до наростання аортальної недостатності у віддаленому періоді, що може стати приводом до повторних оперативних втручань.

\section{Список використаних джерел References}

1. Dorobantu DM, Taliotis D, Tulloh RM, Sharabiani MTA, Ahmed EM, Angelini GD, Stoica SC. Surgical versus balloon valvotomy in neonates and infants: results from the UK National Audit. Open Heart. 2019;6:e000938. http:// dx.doi.org/10.1136/openhrt-2018-000938
2. Torres A, Vincent JA, Everett A, Lim S, Foerster SR, Marshall AC, et al. Balloon valvuloplasty for congenital aortic stenosis: Multi-center safety and efficacy outcome assessment. Catheter Cardiovasc Interv. 2015 Nov;86(5): 808-20. http://dx.doi.org/10.1002/ccd.25969

3. Hochstrasser L, Ruchat P, Sekarski N, Hurni M, von Segesser LK. Long-term outcome of congenital aortic valve stenosis: predictors of reintervention. Cardiol Young. 2015 Jun;25(5):893-902. http://dx.doi. org/10.1017/S1047951114001085

4. Eicken A, Georgiev S, Balling G, Schreiber C, Hager A, Hess J. Neonatal balloon aortic valvuloplasty-predictive value of current risk score algorithms for treatment strategies. Catheter Cardiovasc Interv. 2010 Sep 1;76(3):404-10. http://dx.doi.org/10.1002/ccd.22363

5. Siddiqui J, Brizard CP, Galati JC, Iyengar AJ, Hutchinson D, Konstantinov IE, et al. Surgical valvotomy and repair for neonatal and infant congenital aortic stenosis achieves better results than interventional catheterization. J Am Coll Cardiol. 2013 Dec 3;62(22):2134-40. http://dx.doi.org/10.1016/j. jacc.2013.07.052

6. Brown JW, Rodefeld MD, Ruzmetov M, Eltayeb O, Yurdakok O, Turrentine MW. Surgical valvuloplasty versus balloon aortic dilation for congenital aortic stenosis: are evidence-based outcomes relevant? Ann Thorac Surg. 2012 Jul;94(1):146-53; discussion 153-5. http://dx.doi.org/10.1016/j.athoracsur.2012.02.054

\title{
Comparative Characteristics of Surgical Treatment and Balloon Aortic Valvuloplasty in Infants with Critical Aortic Stenosis
}

\author{
Imanov E. ${ }^{1}$, Truba Y. ${ }^{1}$, Dzyurii I. ${ }^{1}$, Pliska O. ${ }^{3}$, Lazoryshynets V. ${ }^{1,2}$ \\ ${ }^{1}$ National Amosov Institute of Cardiovascular Surgery, Kyiv, Ukraine \\ ${ }^{2}$ Shupyk National Medical Academy of Postgraduate Education, Kyiv, Ukraine \\ ${ }^{3}$ National Pedagogical Dragomanov University, Kyiv, Ukraine
}

\section{Abstract}

Critical aortic stenosis (AS) in infants is a complex pathology requiring emergency care. Treatment for such patients is a challenging problem. The methods of treatment include balloon valvuloplasty and open surgical valvuloplasty.

The objective of the work is to analyze actual experience of surgical treatment and balloon valvuloplasty of critical aortic stenosis in infants.

Materials and methods. For the period from 2006 to 2018, 58 infants with aortic stenosis were treated at the National Amosov Institute of Cardiovascular Surgery. Of these, 47 (81\%) patients (Group 1) had balloon valvuloplasty of the aortic stenosis and 11 (19\%) patients (Group 2) had surgical treatment.

Results and discussion. After balloon valvuloplasty, there was significant reduction in the pressure gradient on the aortic valve in patients of the Group 1, as well as increase in the left ventricular ejection fraction; however, in the medium-term follow-up, the aortic valve pressure gradient increased in most patients, and aortic insufficiency began to increase. After surgical repair, good immediate and medium-term outcomes were observed in terms of the pressure gradient on the aortic valve and the degree of insufficiency.

Conclusion. Surgical as well as balloon valvuloplasty are effective methods of AS treatment in infants with good immediate outcomes. The study suggests that balloon valvuloplasty may be an acceptable alternative to surgical treatment in patients in critical condition with signs of severe heart failure, but is associated with the increase in aortic insufficiency in long-term follow-up.

Keywords: aortic stenosis, surgical aortic valvuloplasty, balloon valvuloplasty, infants. 